\title{
Pengaruh CRM Terhadap Kepercayaan Konsumen serta Dampaknya Terhadap Loyalitas Pelanggan (Survey pada Petani Desa Donowarih, Kecamatan Karangploso, Kabupaten Malang)
}

\author{
The Effect Of CRM on Consumer Trust and Its Impact on Customer Loyalty \\ (Base on Farmerssurvey at Donowarih Village, Karangploso Districts, \\ Malang Regency)
}

\author{
M. Wildan Habibillah, Egha Gyska Amanda, Vina Chandrawati, Zeni Firdayani, \\ Randy Pribadi, Ardita Kurniawan \\ Fakultas Ilmu Administrasi Universitas Brawijaya Malang \\ Jl. MT. Haryono No. 163 Malang 65145
}

DOI:https:/ / doi.org/10.32781/cakrawala.v12i1.263

Received : 27 Januari 2018

Accepted : 9 Mei 2018

Published : 21 Mei 2018

\begin{abstract}
Abstrak:
Kepercayaan konsumen dinyatakan sebagai komponen penting untuk menjaga hubungan yang berkelanjutan diantara semua pihak yang terlibat dalam bisnis. Apabila kepercayaan pelanggan terhadap suatu layanan yang diberikan oleh pelaku bisnis sudah terbangun maka akan memunculkan loyalitas terhadap pelaku bisnisnya. Kepercayaan dan loyalitas tercipta apabila kegiatan Customer Relationship Management (CRM) terlaksana dengan baik.Bentuk layanan CRM ini terdapat di Desa Donowarih.Jenis penelitian yang digunakan dalam penelitian ini adalah explanatory dengan pendekatan kuantitatif. Tujuan penelitian ini adalah untuk mengetahui pengaruh Customer Relationship Management terhadap kepercayaan konsumen serta dampaknya terhadap loyalitas pelanggan survey pada petani Desa Donowarih, Kecamatan Karangploso, Kabupaten Malang
\end{abstract}

Katakunci : Kepercayaan Konsumen, Loyalitas Pelanggan, Customer Relationship Managemen

\begin{abstract}
:
Consumer trust is expressed as an important component to maintaining a sustainable relationship among all parties involved in the business. If the consumer trust has been built then will bring loyalty to the business. Trust and loyalty is created when the activities of Customer Relationship Management performed well. This form of CRM service is located in Donowarih Village. Type of research used in this research is explanatory with quantitative approach. The purpose of this study is to determine the influence of Customer Relationship Management to consumer trust and its impact on customer loyalty survey on farmers Donowarih Village, District Karangploso, Malang regency.
\end{abstract}

Keywords : Consumer trust, Customer Loyalty, Customer Relationship Management

How to Cite:

M. Wildan Habibillah, Egha Gyska Amanda, Vina Chandrawati, Zeni Firdayani, Randy Pribadi, Ardita Kurniawan (2018). Pengaruh CRM Terhadap Kepercayaan Konsumen serta Dampaknya Terhadap Loyalitas Pelanggan (Survey pada Petani Desa Donowarih, Kecamatan Karangploso, Kabupaten Malang). Cakrawala, 12(1), 25-39. 


\section{Pendahuluan}

Menurut pendapat Zur, et al. (2012) menyatakan bahwa kepercayaan konsumen dinyatakan sebagai komponen penting untuk menjaga hubungan yang berkelanjutan diantara semua pihak yang terlibat dalam bisnis. Melalui kepercayaan yang terbangun diantara berbagai pihak yang terlibat dalam bisnis memungkinkan bisnis bisa terjalin dengan lebih intensif mengingat masing-masing pihak memiliki kepercayaan untuk bisa memenuhi tanggung jawabnya. Selain itu, apabila kepercayaan pelanggan terhadap suatu layanan yang diberikan oleh pelaku bisnis sudah terbangun maka akan memunculkan loyalitas terhadap pelaku bisnisnya. Loyalitas adalah suatu kesediaan pelanggan untuk melanjutkan pembelian pada sebuah perusahaan dalam jangka waktu yang panjang dan menggunakan produk atau pelayanannya secara berulang, serta merekomendasikannya kepada teman-teman dan perusahaan lain secara sukarela (Lovelock, et al., 2012). Kepercayaan dan loyalitas tercipta apabila kegiatan Customer Relationship Management (CRM) terlaksana dengan baik. Salah satu bentuk pelayanan yang terdapat di Customer Relationship Management (CRM) ini adalah pemberian modal. Bentuk layanan CRM ini terdapat di Desa Donowarih, Kecamatan Karangploso.

Desa Donowarih merupakan salah satu desa agraris di kecamatan Karangploso kota Malang dimana hasil panen yang dominan adalah tebu dan jeruk. Hal tersebut dikarenakan desa Donowarih merupakan salah salah satu desa yang difokuskan untuk tanaman jeruk dan tebu oleh kepala desa Donowarih. Beberapa fenomena yang terjadi di desa Donowarih adalah sebagian besar petani lebih suka untuk menjual hasil panen kepada para pengepul atau tengkulak. Selain hal tersebut petani juga lebih suka untuk meminjam pinjaman modal kepada tengkulak dibandingkan dengan pinjaman yang diberikan pemerintah. Meskipun pemerintah telah menyediakan alternatif pinjaman/kredit yang disalurkan melalui pihak bank ataupun yang disalurkan melalui program kredit usaha tani melalui koperasi yang ada di desa, namun kenyataannya petani lebih memilih meminjam modal kepada pemilik modal/tengkulak. Alasan para petani adalah proses dan syarat/prosedur yang diberlakukan pemerintah akan kredit tersebut menyulitkan petani, sedangkan kalau mereka meminjam modal kepada pemilik modal/tengkulak, prosesnya bisa cepat. Walaupun dalam proses peminjaman tersebut petani terkesan disudutkan karena petani yang diberikan pinjaman harus menjual hasil panen kepada tengkulak yang telah memberikan pinjaman. Dimana dalam kasus ini modal yang dipinjamkan oleh tengkulak di Desa Donowarih akan digunakan oleh petani jeruk dalam mengembangkan pertaniannya seperti membeli bibit unggul, membeli pupuk, atau membeli peralatan pertanian modern seperti traktor.

Berdasarkan latar belakang yang telah diuraikan, peneliti ingin mengetahui lebih lanjut tentang apa saja pengaruh yang ditimbulkan dari CRM (Customer Relationship Management) terhadap kepercayaan dan loyalitas konsumen khususnya petani di Desa Donowarih, Kecamatan Karangploso, Kabupaten Malang. Terkait hal di atas, maka judul yang akan diajukan oleh peneliti untuk penelitian ini adalah "Pengaruh CRM terhadap Kepercayaan Konsumen serta Dampaknya terhadap Loyalitas Pelanggan Survey pada Petani Desa Donowarih, Kecamatan Karangploso"

\section{Tinjauan pustaka}

\section{Customer Relationship Management (CRM)}

Konsep CRM berasal dari konsep pemasaran hubungan (Relationship Marketing) yaitu suatu konsep dimana perusahaan menjalin hubungan dengan stakeholder perusahaan. Terdapat beberapa pengertian atau konsep mengenai CRM diantaranya menurut Lovelock dan Writz (2011:386), Customer Relationship Management menandakan seluruh proses manjalin dan menjaga hubungan dengan pelanggan dimana hubungan tersebut dapat menjadi jalan untuk memaksimalkan loyalitas pelanggan. Sedangkan menurut Kotler dan Keller (2009) menunjukkan CRM merupakan proses mengelola informasi rinci tentang masingmasing pelanggan dan secara cermat mengelola semua "titik sentuhan" pelanggan demi memaksimalkan kesetiaan pelanggan. Berdasarkan hal tersebut dapat disimpulan bahwa Customer Relationship Management merupakan hal yang yang dapat mempengaruhi loyalitas pelanggan dengan menjalin hubungan antara perusahaan dengan customers, dimana strategi bisnis berfokus pada customers. 
1. Dimensi Customer Relationship Management (CRM)

Menurut Lukas dalam Gifano, afif (2012) menyatakan bahwa keberhasilan CRM di tentukan oleh beberapa hal yaitu:

a) Manusia (people)

Dalam hal ini manusia menjadi faktor nomor satu dalam penerapan CRM karena CRM adalah strategi bisnis yang mengelolah hubungan dan relasi antara manusia. Yang dimaksud dalam hal ini adalah karyawan. Karyawan menjadi bagian paling penting dalam menjalankan CRMkarena karyawanlah yang menjalankan hubungan dengan para pelanggan. Karyawan juga yang menjadi pelaksana apa yang diinginkan oleh perusahaan dan karyawan berusaha memenuhi apa keinginan pelanggan. Dengan adanya penerapan CRM telah terjadi suatu perubahan paradigma pemasaran, bila sebelumnya produksi menjadi fokus utama maka dalam penerapan CRM, pelangganlah yang menjadi fokus utama.

b) Proses (Process)

Pada CRM seluruh fungsi usaha yang ada harus berfokus kepada pelanggan. Baik proses usaha yang melibatkan pelanggan secara langsung maupun yang tidak. Berikut proses-proses CRM:

1) Identifikasi

Identifikasi dapat dilakukan berdasarkan data informasi yang perusahaan terima tentang customers mereka. Identifikasi pelanggan berdasarkan data yang ada, siapa pelanggan yang menguntungkan, dia tinggal dimana dan mengapa dia menguntungkan bagi perusahaan, menjadi hal yang penting tidak hanya berpusat pada nominal keuntungan yang diraih oleh perusahaan. Kebanyakan perusahaan hanya peduli seberapa besar keuntungan yang diperoleh dari pelangganya tanpa tahu siapa pelangganya yang telah memberikan keuntungan.

2) Diferensiasi

Pada tahap ini pelanggan dikelompokan menjadi beberapa kelompok. Hal ini ditujukan agar perusahaan dapat membuat strategi layanan dan memfokuskan energinya pada setiap kelompok.

3) Interaksi

Membuat startegi interaksi dengan para pelanggan untuk menciptakan kesetiaan pelanggan. Semakin lama interaksi terjadi, semakin tahu satu sama lain, semakin enggan pelanggan pindah kepesaing karena pelanggan akan merasa berat untuk memulai hubungan baru dengan pesaing. Interaksi dapat dilakukan dengan email, telepon dan fax, surat, serta tatap muka.

4) Personalisasi

Produk maupun program loyalitas yang disesuaikan dengan keinginan pelanggan secara terus-menerus menggunakan semua informasi yang telah didapat sebelumnya untuk membuat barang dan jasa sesuai dengan keinginan dan kebutuhan pelanggan

c) Teknologi (Technology)

Teknologi memiliki peranan dalam CRM. Pertama, adalah membangun database pelanggan melalui sistem operasi hingga interaksi. Kedua, menganalisa siapa pelanggan paling bagus, dia beli apa, berapa sering. Ketiga, melaksanakan aktifitas penjualan, marketing dan customer service dengan menyatukan saluran komunikasi berbeda (operational CRM). Salah satunya adalah dengan digital marketing. Digital Marketing adalah pemanfaatan teknologi untuk membangun hubungan antara perusahaan dan konsumen yang telah teridentifikasi. Pengguna teknologi yang digunakan yaitu:

1) Website

Perusahaan Website merupakan komponen besar yang sebaiknya dimiliki oleh setiap perusahaan, karena selain berfungsi sebagai halaman informasi yang resmi mengenai sebuah perusahaan, juga bisa digunakan untuk membangun brand. Oleh karena itu website perusahaan harus jelas dan memenuhi kebutuhan informasi yang dicariolehkonsumen 
2) E-mail

Direct Marketing Database e-mail pelanggan sangat penting untuk dimiliki karena memiliki peran yang sangat strategis dalam menjaga loyalitas pelanggan. Database ini bisa digunakan untuk mengirimkan infomasi mengenai produk terbaru, penawaran khusus, atau bahkan untuk menyebar invitation. Hal ini sudah didukung dengan fitur email blast yang dapat mengiriman email secara langsung kepada seluruh konsumen.

3) Social Media

Social Media adalah media yang sangat efektif untuk membangun interaksi yang baik dengan konsumen dan membantu mempertahankan loyalitas pelanggan, selain efektif social media dapat menekan cost. Dengan interaksi yang baik ini perusahaan akan memperoleh feedback dari konsumen untukmembangun produk dari twitter, facebook, youtube, dan instagram.

4) Knowledge

Pengetahuan sangatlah diperlukan dalam kegiatan-kegiatan customer relationship management yang dimana diperlukan untuk mendukung aktivitas fungsionalnya dalam melayani pelanggan. Kemudian diperlukan orang atau karyawan dari perusahaan yangmemilikikemampuan, keterampilan dan sikap yang bertanggung jawab dalam menjalankan customer relationship management agar bisa berjalan dengan lancar dan dapat memenuhi keinginan konsumen, setelah itu, dalam kegiatan menjalankan customer relationship management, tentunya terdapat proses yang perlu dilakukanuntukmeyakinkan tujuan dari CRM tercapai seperti melalui interaksi transaksional dengan pelanggan, yang dimana terdapat hubungan dua atau lebih pihak yang berhubungan. Selain itu, pengetahuan dan wawasan karyawan sangatlah diperlukan untuk menarik pelanggan sehingga pelanggan sendiri mendapatkan pengetahuan dan wawasan baru sehingga meningkatkan nilai pelanggan secara signifikan.
2. Manfaat Customer Relationship Management (CRM)

Menurut Tunggal (2008:10) menyatakan manfaat CRM (Customer Relationship Management) adalah sebagai berikut:

a) Mendorong Loyalitas

Pelanggan dengan menerapkan CRM perusahaan dapat menggunakan informasi mengenai pelanggan secara maksimal. Informasi tersebut dapat digunakan untuk berbagai hal seperti peningkatan pelayanan untuk peningkatan kepuasan pelanggan. Peningkatan kepuasan juga akan berdampak kepadaloyalitaskonsumen. Sehingga perusahaan berfokus kepada konsumen

b) Mengurangi Biaya

Dengan menerapkan CRM dapat mengurangi biaya - biaya yang tidak diperlukan. Perusahaan dapat menganalisa kebutuhan konsumen berdasarkan data yang ada, sehingga perusahaan dapat lebih berfokus terhadap kebutuhan konsumen dan menghemat biaya dan waktu.

c) Meningkatkan Efisiensi Operasional Otomasi penjualan dan proses layanan dapat mengurangi resiko turunnya kualitas pelayanan dan mengurangi beban cash flow. Pengguna teknologi web dan call center misalnya, akan mengurangi hambatan birokrasi dan biaya serta proses adminitrasi yang mungkin timbul.

d) Peningkatan Time To Market Aplikasi CRM memungkinkan kita membawa produk ke pasar dengan lebih cepat dengan informasi pelanggan yang lebih baik, adanya data trend pembeli oleh pelanggan, sampai integrasi dengan aplikasi ERP untuk keperluan perencanaan yang lebih baik. Dengan kemampuan penjualan di web, maka hambatan waktu, geografis, sampai ketersediaan 16 sumber data dapat dikesampingkan untuk mempercepat penjualan produk tersebut. 


\section{Kepercayaan}

1. Definisi Kepercayaan Konsumen

Kepercayaan merupakan tulang punggung dari sebuah bisnis. Membangun kepercayaan untuk hubungan jangka panjang dengan konsumen adalah suatu faktor yang penting untuk menciptakan loyalitas konsumen. Kepercayaan tidak mudah untuk didapatkan oleh semua konsumen, untuk mendapatkan kepercayaan dari konsumen harus dibagun sejak awal dan dipertahankan sampai akhir Zeithaml (2006:119), menyebutkan bahwa kepercayaan terhadap penyedia jasa adalah rasa aman dan terpenuhinya harapan konsumen, sementara Young (2006:1) mendefinisikan konsep kepercayaan sebagai gabungan antara emosi dan penilaian yang dapat berkembang dan berubah seiring perkembangan waktu. Dari beberapa pengertian di atas, dapat ditarik kesimpulan bahwa kepercayaan konsumen adalah sebuah perasaan yang timbul dari konsumen untuk bergantung pada produk atau jasa perusahaan berdasarkan pada pengalaman konsumen

2. Komponen Kepercayaan Konsumen Young and Daniel (2006:3) dalam jurnalnya yang berjudul Trust: Looking Forward and Back merangkum komponen dan hubungan yang akan membentuk trust dalam hubungan bisnis. Terdapat dua elemen didalamnya, yaitu emotional elements (emotion mix) dan calculations elements (assessment mix). Dalam hal ini, komponen emosi dibedakan atas tiga fungsi, antara lain:

a) Membangun sebuah hubungan ( to allow the building)

Emosi yang dapat membangun hubungan yang baik dengan konsumen. Hubungan tersebut dapat menyebabkan konsumen memiliki perasaan tertarik, kagum dan puas terhadap kinerja jasa

b) Menjaga sebuah hubungan (sustaining)

Jenis hubungan ini dapat menjaga hubungan yang positif antara konsumen dengan perusahaan sehingga konsumen merasa aman dan percaya terhadap kinerja perusahaan

c) Menikmati sebuah hubungan (enjoying) Hubungan yang dibina oleh perusahaan dengan konsumen akan membawa kepuasan bagi konsumen, sehingga konsumen meikmati hubungan yang dengan perusahaan. Konsumen juga akan memberikan apresiasi dan penilaian baik terhadap perusahaan. Itulah salah satu kunci dalam menikmati hubungan yang saling menguntungkan.

3. Dimensi Kepercayaan Konsumen

Menurut Mayer et al. Yang dikutip oleh Ainur Rofiq (2007) faktor yang membentuk kepercayaan seseorang terhadap yang lain ada tiga yaitu kemampuan, kebaikan hati, dan integritas. Ketiga faktor tersebut dapat dijelaskan sebagai berikut:

a) Kemampuan

Kemampuan mengacu pada kompetensi. Dalam hal ini, bagaimana penjual mampu menyediakan, melayani, sampai mengamankan transaksi dari gangguan pihak lain. Artinya bahwa konsumen memperoleh jaminan kepuasan dan keamanan dari penjual dalam melakukan transaksi.

b) Kebaikan

Kebaikan hati merupakan kemauan penjual dalam memberikan kepuasan yang saling menguntungkan antara dirinya dengan konsumen. Profit yang diperoleh penjual dapat dimaksimumkan, tetapi kepuasan konsumen juga tinggi. Penjual bukan semata-mata mengejar profit maksimum semata, melainkan juga memiliki perhatian yang besar dalam mewujudkan kepuasan konsumen.

c) Integritas

Integritas berkaitan dengan bagaimana perilaku atau kebiasaan penjual dalam menjalankan bisnisnya. Informasi yang diberikan kepada konsumen apakah benar sesuai dengan fakta atau tidak. Kualitas produk yang dijual apakah dapat dipercaya atau tidak.

\section{Loyalitas Pelanggan}

1. Definisi Loyalitas Pelanggan

Menurut Oliver yang dikutip Hurriyati (2010:128) mengungkapkan definisi loyalitas konsumen sebagai berikut: 26 "Costumer Loyalty is deeply held commitment to rebuy or repatronize a preferred product or service consistently in the future, despite situational influence and marketing efforts having the potential to cause switching behavior" Dari definisi tersebut dapat disimpulkan bahwa 
loyalitas adalah keinginan pelanggan untuk membeli produk secara terus menerus kepada perusahaan baik dimasa sekarang maupun dimasa depan, meskipun ada pengaruh situasi dan usaha-usaha pemasaran mempunyai potensi untuk menyebabkan perubahan.

Menurut Griffin yang dikutip Hurriyati (2010:128), "Loyalty is defined as non random purchase expressed over time by some decision making unit". Berdasarkan definisi tersebut dapat dijelaskan bahwa loyalitas adalah kemampuan mengambil keputusan oleh pelanggan untuk melakukan pembelian secara terus menerus terhadap barang/jasa suatu perusahaan yang dipilih. Dari definisidefinisi tentang loyalitas pelanggan tersebut dapat diambil kesimpulan bahwa loyalitas pelanggan adalah sikap atau perilaku pelanggan atas pengambilan keputusan dalam melakukan pembelian ulang terhadap suatu produk atau jasa.

2. Indikator Loyalitas Konsumen

Konsumen yang loyal merupakan aset yang tidak ternilai bagi perusahaan. Bagaimana menilai konsumen itu loyal atau tidak, Tjiptono (2000:100-108) mengemukakan beberapa karakteristik konsumen yang loyal, diantaranya adalah:

a. Melakukan pembelian yang konsisten Konsumen membeli kembali produk yang sama yang ditawarkan oleh perusahaan.

b. Merekomendasikan produk perusahaan kepada orang lain Konsumen melakukan komunikasi dari mulut ke mulut berkenaan dengan produk tersebut kepada orang lain.

c. Konsumen tidak akan beralih ke produk pesaing. Konsumen tidak tertarik terhadap produk sejenis dari perusahaan lain.

Berdasarkan uraian diatas maka dapat disimpulkan beberapa indikator dari loyalitas konsumen yaitu 1) melakukan pembelian secara konsisten; 2). Konsumen tidak akan terpengaruh dan beralih ke produk pesaing; 3) Merekomendasikan produk perusahaan kepada orang lain.

\section{Hubungan Antar Variabel}

\section{CRM dan Kepercayaan Konsumen}

Customer Releationship Managemen (CRM) merupakan suatu konsep yang dilakukan perusahaan untuk membangun hubungan dengan konsumen sehingga timbul loyalitas dari konsumen. Salah satu dimensi menurut Giffano,afif (2012) dalam membangun loyalitas konsumen dari CRM ialah proses. Proses Interaksi yang terus menerus antara pelaku usaha dan pelanggan akan menimbulkan kenyaman bahkan kepercayaan. Salah satu aspek penting dalam bisnis menurut Zeithaml (2006:119), menyebutkan bahwa kepercayaan terhadap penyedia jasa adalah rasa aman dan terpenuhinya harapan konsumen, sementara Young (2006:1) mendefinisikan konsep kepercayaan sebagai gabungan antara emosi dan penilaian yang dapat berkembang dan berubah seiring perkembangan waktu. Jadi kepercayaan bisa timbul dari proses interaksi yang terus menerus antara penjual dan pelanggan.

Tujuan dari CRM adalah membangun loyalitas konsumen. Kepercayaan bisa dikatakan kepercayaan menjadi sebagai mediator menuju loyalitas. Membangun kepercayaan konsumen juga perlu ada andil dari CRM yang baik sehingga timbul kepercayaan dari konsumen.

\section{CRM dan Loyalitas Pelanggan}

Hubungan antara CRM dan loyalitas pelanggan sangatlah erat sebab memang tujuan CRM adalah untuk membangun loyalitas Pelanggan. Konsep mengenai CRM menurut Lovelock dan Writz (2011:386), Customer Relationship Management menandakan seluruh proses manjalin dan menjaga hubungan dengan pelanggan dimana hubungan tersebut dapat menjadi jalan untuk memaksimalkan loyalitas pelanggan. Hal serupa ditambahkan oleh Kotler dan Keller (2009) menunjukkan CRM merupakan proses mengelola informasi rinci tentang masing-masing pelanggan dan secara cermat mengelola semua "titik sentuhan" pelanggan demi memaksimalkan kesetiaan pelanggan.

Penjelasan dan definisi dari beberapa ahli menunjukkan bahwa terdapat hubungan keterkaitan antara CRM dan loyalitas pelanggan. Hubungan yang baik dengan pelanggan melaui CRM akan menjadi jembatan dalam proses menumbuhkan loyalitas pelanggan. 


\section{Kepercayaan konsumen dan Loyalitas Pelanggan}

Loyalitas menurut dikutip Hurriyati (2010:128) adalah keinginan pelanggan untuk membeli produk secara terus menerus kepada perusahaan baik dimasa sekarang maupun dimasa depan, meskipun ada pengaruh situasi dan usaha-usaha pemasaran mempunyai potensi untuk menyebabkan perubahan. Sehingga dapat diartikan bahwa nilai dari loyalitas pelanggan adalah konsistensi untuk membeli.

Loyalitas pelanggan tidak kemudian dapat dicapai dengan sendirinya tetapi timbul dari suatu usaha. Selain Customer Releationship Management yang baik membangun kepercayaan konsumen adalah faktor esensial dalam membangun loyalitas konsumen sebab kepercayaan adalah faktor paling penting dalam membangun bisnis. Zeithaml (2006:119), menyebutkan bahwa kepercayaan terhadap penyedia jasa adalah rasa aman dan terpenuhinya harapan konsumen, sementara Young (2006:1) mendefinisikan konsep kepercayaan sebagai gabungan antara emosi dan penilaian yang dapat berkembang dan berubah seiring perkembangan waktu.

\section{Model Konseptual}

Silalahi (2009: 111-114) menyatakan bahwa konsep adalah abstraksi tentang fenomena sosial yang dirumuskan melalui generalisasi dari sejumlah karakteristik peristiwa atau keadaan fenomena sosial. Konsep menunjuk pada suatu fenomena sosial, objek atau peristiwa yang diabstraksi sebagai label atau nama. Berdasarkan rumusan masalah dan kajian pustaka yang telah dikemukakan maka model konseptual dalam penelitian ini adalah :

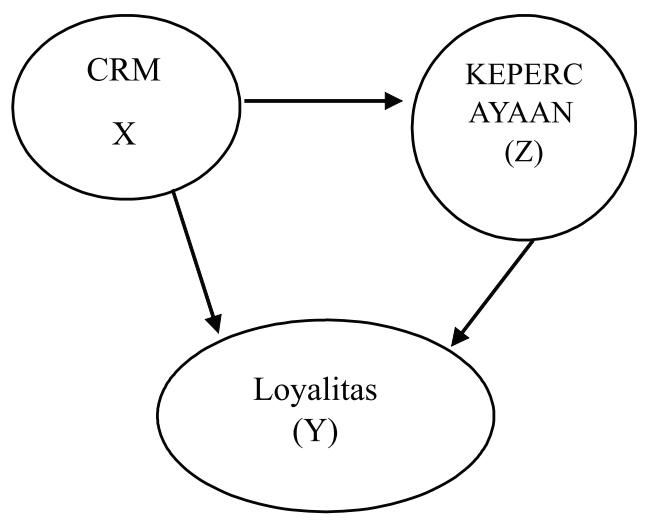

Gambar 2.1 Model Konseptual

\section{Model Hipotesis}

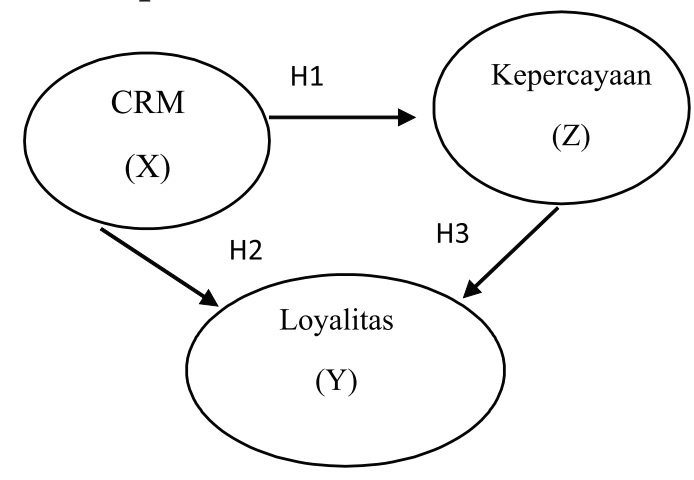

Gambar 2.2 Model Hipotesis

Hipotesis dalam penelitian ini adalah sebagai berikut :

H1 : CRM berpengaruh signifikan terhadap kepercayaan.

H2 : CRM berpengaruh signifikan terhadap loyalitas.

H3 : Loyalitas berpengaruh signifikan terhadap kepercayaan.

H4 : CRM berpengaruh significan terhadap oyalitas melalui kepercayaan konsum.

\section{Metode Penelitian}

Penelitian ini menggunakan jenis penelitian explanatory. Jenis penelitian ini adalah "jenis penelitian yang bertujuan untuk menjelaskan hubungan antara dua atau lebih gejala atau variabel" (Silalahi 2009 : 30). Penelitian ini berfokus kepada penjelasan hubungan variabel dan menguji hipotesis antara CRM dan pengaruhnya terhadap kepercayaan dan loyalitas konsumen survey pada petani jeruk yang berada di Desa Donowarih, Kecamatan Karangploso. Lokasi penelitian merupakan tempat dimana peneliti melakukan dan mengamati kejadian atau permasalahan dalam lokasi tertentu. penelitian ini dilaksanakann di Desa Donowarih terkait hubungan Tengkulak jeruk pada Desa Donowarih, Kecamatan Karangploso, Malang. Populasi dalam penelitian ini adalah seluruh petani jeruk di Desa Donowarih yang menjual ke Tengkulak. Penelitian ini jumlah populasi tidak dapat diketahui oleh peneliti, oleh karena itu penentuan jumlah sampel dapat dicari dengan menggunakan rumus Slovin yaitu:

$$
n=\frac{N}{N \cdot \mathrm{d} 2+1}
$$


Populasi petani di Desa Donowarih sebanyak 586 orang, dengan galat pendugaan (d) sebesar 1\% maka besarnya sampel (n) adalah:

$$
\begin{gathered}
n=\frac{586}{586.0,1^{2}+1} \\
n=85
\end{gathered}
$$

Teknik pengumpulan data dapat melalui wawancara, kuesioner, dan observasi. Instrumen penelitian yang digunakan adalah kuesioner sebelum digunakan diuji validitas dan reliabilitasnya. Teknik analisis data yang digunakan dalam penelitian ini adalahAnalisis dekriptrif dan Path Analysis. Sarwono (2011 : 17) menyebutkan bahwa path analysis merupakan teknik analisis yang digunakan untuk menganalisis hubungan sebab akibat yang inheren antar variabel yang disusun berdasarkan urutan temporer dengan menggunakan koefisien jalur sebagai besaran nilai dalam menentukan besaran pengaruh variabel independen eksogenusterhadap variabelendogenus.

\section{Hasil Dan Pembahasan}

Kecamatan Karangploso merupakan salah satu dari 33 kecamatan yang ada di Kabupaten Malang, Provinsi Jawa Timur serta dilalui jalur utama yang menghubungkan Kota Surabaya dan Kota Batu. Kecamatan Karangploso berbatasan langsung di sebelah utara berbatasan dengan Kecamatan Singosari, sebelah timur berbatasan dengan Kota Malang, sebelah selatan berbatasan dengan Kecamatan Dau, sebelah barat berbatasan dengan Kecamatan Bumiaji, Kota Batu. Kecamatan Karangploso memiliki beberapa desa yang memiliki potensi yang melimpah dan baik untuk di kembangkan salah satunya adalah desa Donowarih. Desa Donowarih adalah salah satu Desa yang memiliki Luas wilayah 1.298 ha.Desa ini terletak sebelah selatan kaki Gunung Arjuna. Desa-desa yang berbatasan antara lain sebelah utara Desa Bocek dan Hutan lindung, sebelah timur Desa Girimoyo dan Bocek, sebelah selatan Desa Pendem Kecamatan Junrejo Kota Batu, sebelah barat Desa Tawangargo. Topografi berupa dataran dan perbukitan serta berada pada ketinggian 600 sampai dengan 950 $\mathrm{m}$ dari permukaan air laut (Litbang,2014).

Responden yang menjadi sampel penelitian ini diklasifikasikan berdasarkan jenis kelamin, dan umur. Sebagian besar responden berumur 31-40 tahun yaitu sebanyak 29 orang dengan perbandingan responden berjenis kelamin laki- laki lebih banyak dibandingkan dengan responden yang berjenis kelamin perempuan.

\section{Gambaran Umum Responden}

Gambaran tentang responden yang menjadi sampel penelitian ini diklasifikasikan berdasarkan jenis kelamin, dan umur. Deskripsi umum atas karakteristik responden dijelaskan sebagai berikut:

\section{Karakteristik Responden Berdasarkan Umur}

Berdasarkan penelitian menunjukan bahwa responden yang berumur antara 21-30 tahun sebanyak 14 orang $(16,3 \%)$, Responden yang berumur 31-40 tahun sebanyak 29 orang (33,7\%), Responden yang berumur 41-50 tahun berjumlah sebanyak 26 orang $(30,2)$, Responden yang berumur 51- 60 tahun berjumlah sebanyak 13 orang $(15,1)$ dan responden yang berumur 61-70 tahun berjumlah sebanyak 4 orang $(4,7)$. Berdasarkan penjabaran tersebut dapat disimpulkan bahwa sebagian besar responden berumur 31-40 tahun yaitu sebanyak 29 orang.

2. Karakteristik Responden Berdasarkan Jenis Kelamin

Berdasarkan penelitian menujukan bahwa responden yang berjenis kelamin laki-laki sebanyak 48 orang $(55,8 \%)$ dan responden berjenis kelamin perempuan sebanyak 38 orang $(44,2 \%)$. Berdasarkan penjelasan tersebut dapat disimpulkan bahwa responden yang berjenis kelamin laki-laki lebih banyak dibandingkan dengan responden yang berjenis kelamin perempuan.

A. Gambaran Distribusi Jawaban Responden

1. Customer Relationship Management (CRM) (X)

Variabel Customer Relationship Management (CRM) terdapat delapan item pertanyaan yang diberikan kepada responden untuk dijawab.

Berdasarkan Jawaban responden menunjukan bahwa untuk item petani yang melakukan hubungan baik dengan tegkulak (X1.1), sebanyak 44 responden $(51,2 \%)$ menjawab sangat setuju, 40 responden $(46,5 \%)$ menjawab setuju, 2 responden (2,3\%) menjawab ragu-ragu. Berdasarkan penjelasan tersebut dapat dilihat bahwa jawaban terbanyak adalah sangat setuju, artinya sebagian besar responden setuju bahwa 
petani di desa donowarih melakukan hubungan baik dengan tengkulak.

Berdasarkan jawaban responden pada tabel 1.3. untuk item tengkulak membuat inovasi untuk membangun relasi (X1.2), sebanyak 26 responden $(30,2 \%)$ menjawab sangat setuju, 50 responden $(58,1 \%)$ menjawab setuju, 10 responden $(11,6 \%)$ menjawab ragu-ragu. Berdasarkan penjelasa tersebut dapat diketahui bahwa jawaban terbanyak menjawab setuju, artinya sebagian besar responden setuju bahwa tengkulak melakukan inovasi untuk membangun relasi dengan petani di desa Donowarih.

Berdasarkan jawaban responden untuk item tengkulak menggunakan tehnologi dalam kegiatannya (X1.3), sebanyak 17 responden (19,8\%) menjawab sangat setuju, 47 responden $(55,7 \%)$ menjawab setuju, 8 respponden $(9,3 \%)$ menjawab ragu-ragu, 10 responden $(11,6 \%)$ menjawab tidak setuju, 4 responden $(4,7 \%)$ menjawab sangat tidak setuju. Berdasarkan penjelasan tersebut diketahui bahwa jawaban terbanyak menjawab setuju, oleh karena itu dapat diartikan bahwa sebagian besar tengkulak menggunakan tehnologi dalam kegiatanya.

Berdasarkan jawaban responden untuk item petani yang merasa penggunaan tehnologi oleh tengkulak sangat bermanfaat dalam menjual hasil panen (X1.4), sebanyak 39 responden $(45,3 \%)$ menjawab sangat setuju, 31 responden $(36,0 \%)$ menjawab setuju, 10 responden (11,6\%) menjawab ragu-ragu, 2 responden (2,3\%) menjawab tidak setuju dan 4 responden $(4,7 \%)$ menjawab sangat tidak setuju. Berdasarkan penjelasan tersebut dapat diketahui bahwa jawaban terbanyak menjawab sangat setuju sehingga dapat disimpulkan bahwa sebagin besar penggunaan tehnologi oleh tengkulak memberikan kebermanfaatan bagi petani.

Berdasarkan jawaban responden untuk item pelayanaan yang ditawarkan oleh tengkulak sesuai dengan keinginan petani (X1.5), sebanyak 38 responden $(44,2 \%)$ menjawab sangat setuju, 38 responden $(44,2 \%)$ menjawab setuju, 2 responden $(2,3 \%)$ menjawab raguragu, 4 responden $(4,7 \%)$ menjawab tidak setuju, 4 responden $(4,7 \%)$ menjawab sangat tidak setuju. Berdasarkan penjelasan tersebut diketahui bahwa sebagian besar pelayanan yang diberikan oleh tengkulak sesuai dengan keinginan petani di desa donowarih.

Berdasarkan jawaban responden untuk item tengkulak memudahkan petani untuk menjual hasil panen (X1.6), sebanyak 35 responden $(40,7 \%)$ menjawab sangat setuju, 31 respnden $(36,0 \%)$ menjawab setuju, 12 responden $(14,0 \%)$ mejawab ragu-ragu, 8 responden $(9,3 \%)$ mejawab tidak setuju. Berdasarkan penjelasan diatas diketahui bahwa jawaban terbanyak menjawab sangat setuju. Oleh karena itu dapat diartikan bahwa keberadaan tengkulak sangat membantu dan memudahkan petani di Donowarih untuk menjual hasil panen.

Berdasarkan jawaban responden untuk item petani mengetahui harga pasar (X1.7) sebanyak 40 responden $(46,5 \%)$ menjawab sangat setuju, sebanyak 27 responden $(31,4 \%)$ menjawab setuju, sebanyak 4 responden $(4,7 \%)$ menjawab raguragu, sebanyak 15 responden $(17,4 \%)$ menjawab tidak setuju. Berdasarkan penjelasan tersebut dapat diketahui bahwa sebagian besar menjawab sangat setuju. Oleh karena itu dapat diartikan bahwa petani di desa donowarih mengetahui harga pasar unuk produk hasil panen.

Berdasarkan jawaban responden. untuk item petani mengetahui keadaan pasar (X1.8), sebanyak 39 responden $(45,3 \%)$ menjawab sangat setuju, 30 responden $(34,9 \%)$ menjawab setuju, 6 responden $(7,0 \%)$ menjawab ragu-ragu, 9 responden $(10,5 \%)$ menjawab tidak setuju dan 2 responden $(2,3 \%)$ menjawab sangat 
tidak setuju. Berdasarkan penjelasan tersebut diketahui bahwa jawaban terbesar menjawab sangat setuju. Oleh karena itu dapat disimpulkan bahwa sebagian besar petani di desa Donowarih mengetahui harga pasar untu produk hasi panen.

\section{Loyalitas Pelanggan (Y)}

Variabel Loyalitas Pelanggan $(\mathrm{Y})$ terdapat enam item pertanyaan yang diberikan kepada responden untuk dijawab. Jawaban responden dapat dilihat berikut ini :

Berdasarkan jawaban responden untuk item petani mendapatkan jaminan terhadap pelayanan yang dilakukan oleh tengkulak (Y1.1), sebanyak 34 responden $(39,5 \%)$ menjawab sangat setuju, 43 responden $(50,0 \%)$ menjawab setuju, 2 responden $(2,3 \%)$ menjawab ragu-ragu, dan 7 responden $(8,1 \%)$ menjawab tidak setuju. Berdasarkan penjelasan tersebut diketahui bahwa jawaban terbesar menjawab setuju sehingga dapat disimpulkan bahwa petani di desa donowarih memperoleh jaminan terhadap pelayanan yang dilakukan oleh tengkulak.

Berdasarkan jawaban responden untuk item petani diberikan ketersediaan pelayanan yang aman oleh tengkulak (Y1.2), sebanyak 38 responden $(44,2 \%)$ menjawab sangat setuju, 34 responden $(39,5 \%)$ menjawab setuju, 8 responden $(9,3 \%)$ menjawab ragu-ragu, 2 responden $(2,3 \%)$ menjawab tidak setuju dan sebanyak 4 responden $(4,7 \%)$ menjawab sangat tidak setuju. Berdasarkan penjelasaan tersebut dapat diketahui bahwa jawaban terbesar menjawab sangat setuju. Oleh karena itu dapat di simpulkan bahwa sebagian besar petani diberikan ketersediaan pelayanan yang aman oleh tengkulak.

Berdasarkan jawaban responden untuk item petani mendapatkan pelayanan yang baik oleh tengkulak (Y1.3), sebanyak 45 responden (52,3\%) menjawab sangat setuju, 25 rseponden $(29,1 \%)$ menjawab setuju, 10 responden $(11,6 \%)$ menjawab ragu-ragu, 6 responden $(7,0 \%)$ menjawab tidak setuju. Berdasarkan penjelasan tersebut dapat diketahui bahwa jumlah jawaban terbanyak menjawab sangat setuju. Oleh karena itu dapat disimpukan bahwa petani memperoleh pelayanan yang baik dari tengkulak.

Berdasarkan jawaban responden untuk item tengkulak selalu melakukan inovasi (Y1.4), sebayak 37 responden $(43,0 \%)$ menjawab sangat setuju, 33 responden $(38,4 \%)$ menjawab setuju, 4 responden $(4,7 \%)$ menjawab raguragu, 10 responden (11,6\%) menjawab tidak setuju dan 2 responden $(2,3 \%)$ menjawab sangat tidak setuju. Berdasarkan penjelasan tersebut dapat diketahui bahwa jawaban terbanyak menjawab sangat setuju. Oleh karena itu dapat disimpulkan bahwa tengkulak di desa donowarih selalu melakukan inovasi dalam kegiatanya.

Berdasarkan jawaban responden untuk item pelayanan yang dilakukan oleh tengkulak terpercaya (Y1.5), sebanyak 34 responden $(39,5 \%)$ menjawab sangat setuju, 30 responden $(34,9 \%)$ menjawab setuju, 12 responden $(14,0 \%)$ menjawab ragu-ragu, 10 responden $(11,6 \%)$ menjawab tidak setuju. Berdasarkan penjelasan tersebut dapat diketahui bahwa jawaban terbanyak menjawab sangat setuju. Oleh karena itu dapat disimpulkan bahwa pelayanan yang diberikan tengkulak kepada petani di desa Donowarih terpercaya.

Berdasarkan jawaban responden untuk item informasi yang diberikan oleh tengkulak sesuai dengan fakta (Y1.6), sebanyak 52 responden $(60,5 \%)$ menjawab sangat setuju, 22 responden $(25,6 \%)$ menjawab setuju, 6 responden $(7,0 \%)$ menjawab ragu-ragu, dan 6 responden $(7,0 \%)$ menjawab sangat tidak setuju. Berdasarkan penjelasan tersebut dapat diketahui bahwa jawaban terbanyak menjawab sangat setuju. Oleh karena itu dapat disimpulkan bahwa informasi yang diberikan tengkulak kepada petani di desa Donowarih sesuai dengan fakta. 


\section{Kepercayaan Konsumen (Z)}

Variabel Loyalitas Pelanggan (Z) terdapat tujuh item pertanyaan yang diberikan kepada responden untuk dijawab. Jawaban responden dapat dilihat berikut ini:

Berdasarkan jawaban responden untuk item petani konsisten dalam memilih tengkulak (Z1.1), sebanyak 45 responden $(52,3 \%)$ menjawab sangat setuju, 31 responden $(36,0 \%)$ menjawab setuju, 2 responden $(2,3 \%)$ menjawab ragu-ragu, 8 responden $(9,3 \%)$ menjawab tidak setuju. Berdasarkan penjelasan tersebut diketahui bahwa jumlah jawaban terbanyak menjawab sangat setuju. Oleh karena itu dapat disimpulkan bahwa petani di desa Donowarih konsisten dalam memilih tengkulak.

Berdasarkan jawaban responden untuk item petani mendapatkan manfaat dengan danya pelayanan yang diberikan tengkulak (Z1.2), sebanyak 38 responden $(44,2 \%)$ menjawab sangat setuju, 40 responden $(46,5 \%)$ menjawab setuju, 4 responden $(4,7 \%)$ menjawab ragu-ragu, 4 responden $(4,7 \%)$ menjawab tidak setuju. Berdasarkan penjelasan tersebut dapat diketahui bahwa jumlah jawaban terbanyak menjawab setuju. Oleh karena itu dapat disimpulkan bahwa petani di desa Donowarih mendapat manfaat dari adanya tengkulak.

Berdasarkan jawaban responden untuk item petani merasa senang dengan pelayanan yang diberikan tengkulak (Z1.3), sebanyak 38 responden $(44,2 \%)$ menjawab sangat setuju, 36 responden $(41,9 \%)$ menjawab setuju, 8 responden $(9,3 \%)$ menjawab ragu-ragu, 4 responden $(4,7 \%)$ menjawab tidak setuju. Berdasarkan penjelasan tersebut dapat diketahui bahwa jumlah jawaban terbanyak menjawab sangat setuju. Oleh karena itu dapat disimpulkan bahwa petani di desa Donowarih merasa senang dengan pelayanan yang diberikan oleh tengkulak.

Berdasarkan jawaban responden untuk item petani merasa puas dengan pelayanan yang diberikan oleh tengkulak (Z1.4), sebanyak 42 responden $(48,8 \%)$ menjawab sangat setuju, 32 responden $(37,2 \%)$ menjawab setuju, 10 responden (11,6\%) menjawab ragu-ragu, 2 responden $(2,3 \%)$ menjawab tidak setuju. Berdasakan penjelasan tersebut dapat diketahui bahwa jumlah responden yang menjawab sangat setuju. Oleh karena itu dapat disimpulkan bahwa petani di desa Donowarih merasa puas dengan pelayanan yang diberikan oleh tengkulak.

Berdasarkan jawaban responden untuk item petani tidak ingin beralih ke pelayanan lain (Z1.5), sebanyak 37 responden $(43,0 \%)$ menjawab sangat setuju, 31 responden $(36,0 \%)$ menjawab setuju, 14 responden $(16,3 \%)$ menjawab ragu-ragu, dan 4 responden $(4,7 \%)$ menjawab tidak setuju. Berdasarkan penjelasan tersebut dapat diketahui bahwa jawaban responden terbayak menjawab sangat setuju. Oleh karena itu dapat disimpulkan bahwa petani di desa Donowarih tidak ingin beralih dari tengkulak.

Berdasarkan jawaban responden untuk item petani mendapatkan manfaat dari merekomendasikan jasa dari tengkulak (Z1.6), sebanyak 37 responden $(43,0 \%)$ menjawab sangat setuju, 35 responden $(40,7 \%)$ menjawab setuju, 10 responden $(11,6 \%)$ menjawab ragu-ragu, 4 responden $(4,7 \%)$ menjawab tidak setuju. Berdasarkan penjelasan tersebut diketahui bahwa jawaban responden menjawab sangat setuju. Oleh karena itu dapat disimpulkan bahwa petani di desa Donowarih mendapatkan kebermanfaatan dari merekomendasikanjasa dari tengkulak.

Berdasarkan jawaban responden untuk item petani memiliki keinginan untuk merekomendasikan jasa tengkulak kepada orang lain (Z1.7), sebanyak 46 responden $(53,3 \%)$ menjawab sangat setuju, 30 responden $(34,9 \%)$ menjawab setuju, 4 responden $(4,7 \%)$ mejawab ragu-ragu, dan 6 responden $(7,0 \%)$ menjawab tidak setuju. Berdasarkan penjelasan tersebut 
dapat diketahui bahwa jumlah jawaban terbanyak responden menjawab sangat setuju. Oleh karenaitu dapat disimpulkan bahwa petani di desa Donowarih memiliki keinginan untuk merekomendasikan jasa tengkulak kepada orang lain.

\section{Analisis Jalur (Path Analysis)}

\section{Pengujian sub stuktur 1}

Sub-struktur 1 dalam penelitian ini adalah analisis pengaruh Customer Relationship Management $(\mathrm{CRM})(\mathrm{X})$ terhadap kepercayaan Konsumen (Z). Persamaan strukural untuk sub-struktur 1 adalah sebagai berikut:

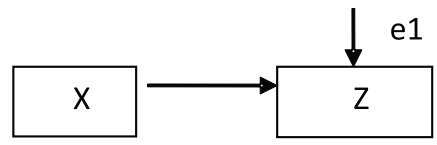

Pengaruh X1 terhadap Kepercayaan Konsumen

\begin{tabular}{cccccl}
\hline Variabel & Beta & T & Sig t & Keterangan \\
\hline $\mathrm{X}$ & 0,677 & 11,904 & 0,000 & Signifikan \\
\hline $\begin{array}{ll}\mathrm{T} \text { tabel }=1,6630 \\
\mathrm{R} \text { square }=0,628\end{array}$ & & & \\
\hline
\end{tabular}

Tabel 4.6 diatas dapat disimpulkan bahwa :

a. Dari nilai $\mathrm{R}$ square menunjukkan nilai sebesar 0,628 atau $62,8 \%$. Artinya bahwa

Kepercayaan Konsumen dipengaruhi sebesar $62,8 \%$ oleh CRM. Sedangkan sisanya sebesar 37,2\% dipengaruhi oleh variable lain di luar variable bebas yang diteliti.

b. Persamaan regresi standardize yang terbentuk: $Y=0,677 X Y$

Darithitung menunjukkan bahwa:

Variabel CRM (X) memiliki nilai t hitung sebesar 11,904 dengan probabilitas sebesar 0,000 . Karena $\mathrm{t}$ hitung $>\mathrm{t}$ tabel $(11,904>1,6630)$ atau sig $\mathrm{t}<5 \%(0,000<$ $0,05)$ maka variabel CRM $(X)$ berpengaruh signifikan terhadap Kepercayaan Konsumen (Y). Pada pengujian tersebut $\mathrm{H}_{0}$ ditolak dan $\mathrm{H}_{2}$ diterima, artinya bahwa ada pengaruh yang signifikan antara variable CRM $(X)$ dan variable Kepercayaan Konsumen $(Y)$.

\section{Pengujian sub stuktur 2}

Sub-struktur 2 dalam penelitian ini adalah analisis pengaruh CRM $(X)$ dan kepercayaan Konsumen ( $Z$ ) terhadap Loyalitas
Pelanggan (Y). Persamaan strukural untuk sub-struktur 2 adalah sebagai berikut :

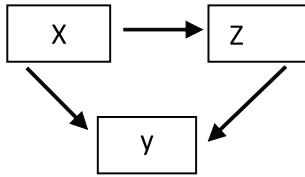

Pengaruh X dan Kepercayaan Konsumen terhadap Loyalitas Pelanggan

\begin{tabular}{lllll}
\hline Variabel & Beta & $\mathrm{T}$ & $\mathrm{Sig} \mathrm{t}$ & Keterangan \\
\hline $\mathrm{X}$ & 0,139 & 1,551 & 0,125 & Tidak signifikan \\
\hline $\mathrm{Y}$ & 0,711 & 6,795 & 0,000 & Signifikan \\
\hline T tabel $=1,6630$ & & & & \\
R square $=0,679$ & & & & \\
\hline
\end{tabular}

Tabel 4.7 diatas dapat disimpulkan bahwa:

a. Dari nilai $\mathrm{R}$ square menunjukkan nilai sebesar 0,679 atau $67,9 \%$. Artinya bahwa Loyalitas pelanggan $(\mathrm{Z})$ dipengaruhi sebesar 67,9\% oleh CRM (X) dan Kepercayaan Konsumen (Y). Sedangkan sisanya $32,1 \%$ dipengaruhi oleh variabel lain diluar variabel bebas yang diteliti.

b. Persamaan regresi standardize yang terbentuk: $Z=0,139 \mathrm{zx}+0,711 \mathrm{yz}$

c. Dari thitung menunjukkan bahwa :

1) Variabel CRM (X) memiliki nilai $t$ hitung sebesar 1,551 dengan probabilitas 0,125. Karena t hitung $<\mathrm{t}$ tabel $(1,551<1,6630)$ atau sig $\mathrm{t}>$ $5 \%(0,125>0,05)$ maka variable CRM (X) tidak berpengaruh signifikan terhadap Loyalitas pelanggan (Z). Pada pengujian tersebut $\mathrm{H} 0$ diterima dan $\mathrm{Ha}$ ditolak, artinya bahwa tidak ada pengaruh signifikan antara variabel CRM (X) terhadap Loyalitas pelanggan $(Z)$.

2) Variabel Kepercayaan Konsumen (Y) memiliki t hitung sebesar 6,795 dengan probabilitas 0,000 . Karena $t$ hitung $>\mathrm{t}$ tabel $(6,795>1,6630)$ atau sig $\mathrm{t}<5 \%(0,000<0,05)$ maka variabel Kepercayaan Konsumen (Y) berpengaruh signifikan terhadap Loyalitas Pelanggan $(Z)$. Pada pengujian tersebut $\mathrm{HO}$ ditolak dan Ha diterima, artinya bahwa ada pengaruh yang signifikan antara variabel Kepercayaan Konsumen ( $(Y)$ dan Loyalitas Pelanggan (Z). 


\section{Pengujian Sub stuktur 3}

Sub-struktur 3 dalam penelitian ini adalah analisis pengaruh kepercayaan Konsumen (Z) terhadap Loyalitas Pelanggan (Y). Persamaan strukural untuk sub-struktur 2 adalah sebagai berikut:

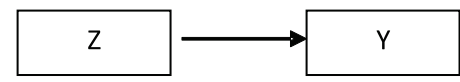

Pengaruh kepercayaan Konsumen (Z) terhadap Loyalitas Pelanggan (Y)

\begin{tabular}{ccccl}
\hline Variabel & Beta & T & Sig t & Keterangan \\
\hline$Z$ & 0,818 & 13,043 & 0,000 & Signifikan \\
\hline \multicolumn{2}{l}{ T tabel $=5,320$} \\
R square $=0,669$ \\
\hline
\end{tabular}

Tabel 4.7 diatas dapat disimpulkan bahwa :

a. Dari nilai Beta menunjukkan nilai sebesar 0,818 atau $81,8 \%$. Artinya bahwa Kepercayaan Konsumen berpengaruh sebesar $81,8 \%$ terhadap loyalitas pelanggan. Sedangkan sisanya sebesar 18,2\% dipengaruhi oleh variable lain di luar variable bebas yang diteliti.

b. Persamaan regresi standardize yang terbentuk: $Z=0,677 Y Z$

Dari thitung menunjukkan bahwa:

Variabel Kepercayaan pelanggan (Z) memiliki nilai $t$ hitung sebesar 13,043 dengan probabilitas sebesar 0,000. Karena $\mathrm{t}$ hitung $>\mathrm{t}$ tabel $(13,043>5,320)$ atau sig $\mathrm{t}<5 \%(0,000<0,05)$ maka variabel Kepercayaan pelanggan (Z) berpengaruh signifikan terhadap Loyalitas Pelanggan (Y). Pada pengujian tersebut $\mathrm{H}_{0}$ ditolak dan $\mathrm{H}_{\mathrm{a}}$ diterima, artinya bahwa ada pengaruh yang signifikan antara variable Kepercayaan pelanggan $(\mathrm{Z})$ dan variable Loyalitas pelanggan $(\mathrm{Y})$.

\section{Pengujian Sub stuktur 4}

Sub-struktur 4 dalam penelitian ini adalah analisis pengaruh CRM (X) dan terhadap Loyalitas Pelanggan (Y). Persamaan strukural untuk sub-struktur 4 adalah sebagai berikut:

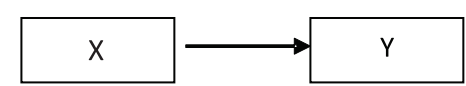

Pengaruh CRM (X) terhadap Loyalitas Pelanggan $(\mathrm{Y})$

\begin{tabular}{ccccc}
\hline Variabel & Beta & T & Sig t & Keterangan \\
\hline $\mathrm{X}$ & 0.707 & 9,166 & 0,000 & Signifikan \\
\hline T tabel $=4,145$ & & & \\
R square $=0,500$ & & & \\
\hline
\end{tabular}

Tabel 4.8 diatas dapat disimpulkan bahwa :

a. Dari nilai Beta menunjukkan nilai sebesar 0,707 atau 70,7\%. Artinya bahwa CRM berpengaruh sebesar 70,7\% terhadap loyalitas pelanggan. Sedangkan sisanya sebesar 29,3\% dipengaruhi oleh variable lain di luar variable bebas yang diteliti.

b. Persamaan regresi standardize yang terbentuk: $\mathrm{X}=0,677 \mathrm{XZ}$

Dari thitung menunjukkan bahwa:

Variabel CRM (X) memiliki nilai thitung sebesar 9,166 dengan probabilitas sebesar 0,000 . Karena $t$ hitung $>t$ tabel $(9,166>4,145)$ atau sig $\mathrm{t}<5 \%(0,000<0,05)$ maka variabel CRM $(X)$ berpengaruh signifikan terhadap Loyalitas Pelanggan (Y). Pada pengujian tersebut $\mathrm{H}_{0}$ ditolak dan $\mathrm{H}_{\mathrm{a}}$ diterima, artinya bahwa ada pengaruh yang signifikan antara variable CRM $(X)$ dan variable Loyalitas pelanggan $(\mathrm{Y})$.

\section{B. Ketepatan Model}

Ketepatan model hipotesis dari data penelitian diukur dari hubungan koefisien determinasi $\left(\mathrm{R}^{2}\right)$ di kedua persamaan. Hasil ketepatan model adalah :

$$
\begin{aligned}
\mathrm{R}^{2} \text { model } & =1-\left(1-\mathrm{R}^{1}\right)\left(1-\mathrm{R}^{2}\right)\left(1-\mathrm{R}^{3}\right)\left(1-\mathrm{R}^{4}\right) \\
& =1-(1-0,628)(1-0,679)(1-0,669)(1-0,500) \\
& =1-(0,372)(0,321)(0,331)(0.500) \\
& =1-(0,119)(0,165) \\
& =1-0,02 \\
& =0,98
\end{aligned}
$$

Hasil perhitungan $\mathrm{R}^{2}$ mengindikasikan keragaman data yang dapat digunakan oleh model tersebut adalah sebesar $88,1 \%$ atau dengan kata lain informasi yang terkandung dalam data 98,\% dapat dijelaskan oleh model path tersebut. Sedangkan 2\% keragaman sisanya dijelaskan oleh variabel lain (yang belum terdapat di dalam model).

\section{Interpretasi Pembahasan}

Berdasarkan hasil analisis dan melalui path analysis diketahui bahwa CRM (X) mempengaruhi kepercayaan konsumen $(\mathrm{Z})$ dan Loyalitas Pelanggan (Y). 
1. Pengaruh Customer Relationship Management (CRM) (X) terhadap Kepercayaan Konsumen (Z)

Berdasarkan hasil perhitungan distribusi frekuensi yang menunjukkan adanya pengaruh signikan variabel CRM (X) terhadap kepercayaan konsumen. Hal tersebut diperoleh sebagaimana dalam sub-struktur 1 pada tabel 4.6. Hasil penelitian ini menunjukkan tingkat kepercayaan konsumen sangat dipengaruhi oleh CRMyang diberikan kepada konsumen.

2. Pengaruh Customer Relationship Management (CRM) (X) dan Kepercayaan Konsumen (Z) terhadap Loyalitas Pelanggan (Y)

Berdasarkan hasil perhitungan menunjukkan bahwa variabel CRM (X) memiliki pengaruh tetapi tidak signifikan terhadap variabel loyalitas pelanggan (Y). Hal tersebut ditunjukkan pada pengujian sub-struktur 2 dalam tabel 4.7. Pernyataan kedua menunjukkan bahwa variabel Kepercayaan Konsumen

(Z) berpengaruh signifikan terhadap Loyalitas Pelanggan (Y). Pada pengujian tersebut $\mathrm{HO}$ ditolak dan $\mathrm{Ha}$ diterima, artinya bahwa ada pengaruh yang signifikan antara variabel Kepercayaan Konsumen (Z) dan Loyalitas Pelanggan (Z).

3. Pengaruh kepercayaan Konsumen (Z) terhadap Loyalitas Pelanggan (Y)

Berdasarkan hasil perhitungan menunjukan bahwa variabel kepercayaan konsumen berpengaruh signifikan terhadap loyalitas pelanggan. Hal tersebut dibuktikan dengan besarnya pengaruh adalah $81,8 \%$ dan hal tersebut sesuai dengan teori yang menyebutkan bahwa terdapat pengaruh yang signifikan antara variabel kepercayaan dan loyalitas pelanggan pada para petani di desa Donowarih dengan para tengkulak.

4. Pengaruh CRM $(X)$ terhadap Loyalitas Pelanggan $(\mathrm{Y})$

Berdasarkan hasil perhitungan menunjukan bahwa variabel CRM memiliki pengaruh terhadap Loyalitas Pelanggan. Hal tersebut dibuktikan dengan besarnya pengaruh sebesar 70,7 \% berdasarkan perhitugan diatas. Berdasarkan hal tersebut di buktikan bahawa teori Zur (2012) benar adanya pengaruh antara variabel CRM denganLoyalitasPelanggan.

\section{Penutup}

\section{Simpulan}

Berdasarkan hasil analisis dan pembahasan yang telah diuraikan pada bab IV, maka dapat diambil kesimpulan untuk menjawab perumusan masalah, yaitu : Terdapat pengaruh yang signifikan antara CRM $(X)$ terhadap kepercayaan konsumen ( $\mathrm{Z}$ ). Ada pengaruh tetapi tidak signifikan antara CRM (X) terhadap loyalitas pelanggan ( $\mathrm{Y})$. Terdapat pengaruh yang signifikan antara Kepercayaan konsumen (Z) terhadap loyalitas pelanggan (Y) Terdapat pengaruh yang signifikan antara Kepercayaan Konsumen (Z) terhadap Loyalitas Pelanggan (Y)

\section{Saran}

Hasil penelitian ini diharapkan dapat memberikan kontribusi praktis bagi perusahaan dan kontribusi teoritis bagi akademisi penelitian, berupa saran konkrit yang mungkin untuk direalisasikan : Terdapat pengaruh yang signifikan antara CRM $(X)$ terhadap kepercayaan konsumen (Z). Hasil dari kesimpulan tersebut menjadi rujukan pada tengkulak untuk terus meningkatkan kualitas Customer Releationship Management (CRM) guna meningkatkan kepercayaan konsumen (petani). Kepercayaan konsumen sangat penting sebab akan mempengaruhi kesetiaan konsumen pada tengkulak. Secara teknis tengkulak bisa melakukan pendekatan keakraban secara personal terhadap petani agar petani selalu nyaman bertransaksi dengan tengkulak. Tengkulak perlu terus meningkatkan inovasi guna membangun relasi dengan petani. Tengkulak bisa memberi bonus penjualan pada petani guna kesejahteraan petani. Tengkulak memberi bibit komoditas pertanian pada petani dengan kualitas baik. Tengkulak besar juga bisa memeberikan pelatihan pertanian modern pada petani guna peningkatan hasil komoditas. 


\section{Daftar Pustaka}

Ardi Nugroho, Listyawan. 2011. Pengaruh Modal Usaha.Yogyakarta:Pustaka Pelajar

Arikunto, S. 2010. Prosedur Penelitian : Suatu Pendekatan Praktik. Jakarta:Rineka Cipta.

Ghozali, Imam. 2006. Aplikasi Analisis Multivariate dengan Program SPSS. Edisi kedua.Yogyakarta : Universitas Diponegor

Hurriyati, Ratih. 2010. Bauran Pemasaran dan Loyalitas Konsumen.Bandung: Alfabeta.

Kotler, Philip, dan Keller. 2009. Manajemen Pemasaran. Edisi 13 Jilid I. PT. Indeks.

Lovelock, Christoper dan Jochen Wirtz. 2011. Service Marketing. New Jersey USA : Pearson.

Nazir. 2003. Metode Penelitian Bisnis. Jakarta : Ghalia Indonesia.

Rofiq, Ainur. 2007. Pengaruh Dimensi Kepercayaan (Trust) terhadap Partisipasi Pelanggan E-Commerce (Study pada Pelanggan E-Commerce di Indonesia) Tesis FPS Universitas Brawijaya Malang : tidak diterbitkan.
Sarwono, Jonathan. 2011. Path Analysis. Jakarta : PT Elex Media Komputindo.

Silalahi, Ulber. 2009. Metode Penelitian Sosial.Bandung: PT. Refika Aditama

Sugiyono. 2007. Statistika untuk Penelitian. Bandung: CV. Alfabeta.

Sugiyono. 2008. Metode Penelitian Bisnis. Bandung: CV. Alfabeta.

Sugiyono. 2012. Metode Penelitian Kuantitatif, Kualitatif, dan RED. Bandung : CV. Alfabeta.

Tjiptono, Fandy. 2000. Manajemen Jasa. Yogyakarta: Andi Offset.

Zur, A., Leckie, C., \& Webster, C. M. (2012).Cognitive and Affective Trust between Australian Exporters and Their Overseas Buyers. Australasian Marketing Journal, 20(1), 73-79. (Online) Diakses melalui http://www.datadanesh.com/freear ticle/2006.pdf (29September 2017). 